\title{
Analisis Konsep Tilakkhana dalam Kehidupan Masyarakat Buddhis
}

\section{Sarwi $^{1}$}

\begin{abstract}
Abstrak
Penelitian ini bertujuan untuk menganalisis tingkat pemahaman dan penerapan konsep Tilakkhana dalam kehidupan masyrakat Buddhis. Salah satu konsep dalam Agama Buddha yang dipelajari secara turun temurun diwariskan dari generasi ke generasi. Penelitian ini merupakan penelitian kualitatif. Data dikumpulkan dengan cara observasi secara langsung, dokumentasi dilapangan, dan wawancara dengan informan. Informan dalam penelitian ini adalah beberapa tokoh masyarakat Agama Buddha di dusun Glagah desa Giling kecamatan Gunungwungkal kabupaten Pati. Berdasarkan deskripsi data dan analisis data dapat diketahui dan dapat ditemukan bahwa tingkat pemahaman konsep Tilakkhana umat Buddha di dusun Glagah sangat kurang, tetapi secara tidak langsung sudah menerapkan konsep Tilakhana dalam kehidupan. Implikasi yang terbentuk adalah mempertahankan dan melestarikan nila-nilai ajaran Agama Buddha.
\end{abstract}

Kata kunci: Tilakkhana, Kehidupan, Masyarakat Buddhis

\begin{abstract}
This study aims to analyze the level of understanding and application of the Tilakkhana concept in the life of the Buddhist community. One of the concepts in Buddhism that is learned from generation to generation is passed down from generation to generation. This research is a qualitative research. Data was collected by direct observation, documentation in the field, and interviews with informants. The informants in this study were several Buddhist community leaders in Glagah subvillage, Giling village, Gunungwungkal district, Pati district. Based on the data description and data analysis, it can be seen and can be found that the level of understanding of the Tilakkhana concept of Buddhists in Glagah hamlet is very lacking, but indirectly has applied the Tilakhana concept in life. The implications formed are to maintain and preserve the teachings of Buddhism.
\end{abstract}

Keywords: Tilakkhana, Life, Buddhist Society.

${ }^{1}$ STABN Raden Wijaya, email: sarwiputra6@gmail.com 


\section{Pendahuluan}

$\begin{array}{rrr}\text { Semua } & \text { manusia } & \text { pernah } \\ \text { mengalami } & \text { kehidupan. } & \text { Sebagian }\end{array}$
manusia memiliki pandangan bahwa kehidupan adalah penderitaan atau hidup adalah derita. Sesungguhnya kehidupan adalah penderitaan, ketika manusia dilahirkan, manusia sudah mengalami penderitaan, hal ini dibuktikn dengan tangisan bayi pada saat dilahirkan. Dalam konsep ajaran agama Buddha penyebab penderitaan yaitu lobha (keserakahan), dosa (kebencian), dan moha (kebodohan batin). Selama manusia masih dalam lingkaran lobha, dosa, dan moha, manusia masih merasakan penderitaan didalam kehidupan duniawi. Dengan adanya hal tersebut, dalam ajaran agama Buddha mengajarkan konsepkonsep bagaimana cara untuk terbebas dari penderitaan.

Banyak konsep-konsep ajaran agama Buddha yang bertujuan memutus rantai penderitaan duniawi. Salah satu konsep ajaran agama Buddha yang menjadi pokok dasar ajaran agama Buddha adalah tilakkhana. Tilakkhana merupakan salah satu konsep mendasar dalam agama Buddha, hendaknya umat Buddha telah mengetahui konsep mendasar tersebut. Akan tetapi banyak masyarakat Buddhis di desa Giling kecamatan Gunungwungkal kabupaten Pati yang belum mengetahui konsep ini, tanpa disadari konsep ini sudah menjadi keseharian dalam kehidupan masyarakat Buddhis di desa Giling. Masyarakat Buddhis di desa Giling sudah mempraktikan dalam kehidupan sehari-hari, tetapi masyarakat Buddhis di desa Giling belum menyadarinya. Umat Buddhis di desa Giling memiliki kecenderungan rasa malas untuk membaca buku atau pengetahuan lainnya, masyarakat Buddhis di desa Giling memiliki rasa keinginan untuk belajar hanya pada hal-hal yang sifatnya berhubungan dengan pekerjaan atau perekonomian. Disini masalah muncul karena masyarakat Buddhis di Desa Giling tidak mengimbangi dengan belajar pada hal-hal yang bersifat kerohanian.

Tilakkhana berisi tentang tiga corak yang bersifat umum dan saling bergantungan antara satu dengan lainnya, artinya tiga corak ini selalu mengikuti dalam diri manusia dan tidak bisa dipisahkan. Selama kehidupan masih ada, tilakkhana masih mengikuti kemanapun manusia berada. Hukum Tilakkhana ini mengacu pada 3 corak kehidupan yang pasti terjadi dan terdapat pada segala sesuatu yang berkondisi (Sasanasena Seng Hansen, $2008: 11)$. 
Ketiga corak tersebut dapat disadari dan dipraktikan dalam kehidupan masyarakat Buddhis di Desa Giling. Masyarakat Buddhis di desa Giling hendaknya dapat menyadari dengan apa yang telah dilakukan baik lewat pikiran, ucapan, maupun berbuatan. Selain menyadari dengan apa yang telah dilakukan lewat pikiran, ucapan, maupun berbuatan, masyarakat Buddhis di desa Giling menyadari adanya ketidakkekalan, semua yang dimiliki akan berubah dan akan terlepas, apabila masyarakat Buddhis di desa Giling tidak mampu untuk menyadari dan mengikis ke aku-an dalam kehidupan, penderitaan akan selalu mengikuti. Dengan kesadaran akan menyebabkan kebijaksanaan dalam setiap perbuatan yang dilakukan, lebih hati- hati dalam berbicara dan bertindak. Masyarakat Buddhis di desa Giling hendaknya berusaha untuk mempelajari konsep-konsep ajaran agama Buddha.

Penelitian konsep ajaran Buddha dimasyarakat sudah dilakukan oleh para peneliti terdahulu yang relevan dengan bidang studi konsep dasar agama Buddha adalah sebagai berikut. Hanafi (2018) dalam penelitian yang berjudul "Dampak Ajaran Dharma Terhadap Kehidupan Keberagamaan Bagi Jamaat Vihara Budddha Kirti
Surabaya" mengkaji tentang konsep dan pratik ajaran Dharma dan dampak di masyarakat. Achmad Muzaki (2013) dalam penelitian yang berjudul "Konsep Trikaya Dalam Agama Buddha Mahayana" mengkaji tentang konsep trikaya dan timbulnya konsep trikaya dalam ketuhanan agama Buddha Mahayana. Suranto (2013) dalam penelitian yang berjudul "Kompleksitas Pemaknaan Bhavana Di Kalangan Umat Buddha" mengkaji tentang bentuk kompleksitas pemaknaan Bhavana dikalangan umat Buddha.

Berdasarkan beberapa permasalahan tersebut di atas, penulis bermaksud untuk melakukan penggalian lebih mendalah tentang konsep Tilakkhana. Langkah yang ditempuh oleh penulis adalah dengan melakukan penelitian lebih mendalam dengan judul: "Konsep Tilakkhana Dalam Kehidupan Masyarakat Buddhis". Penelitian tersebut perlu dilakukan guna mengetahui seberapa jauh pemahaman dan penerapan konsep Tilakkhana didalam kehidupan masyarakat Buddhis.

\section{Metode}

Lokasi yang menjadi objek dalam penelitian ini adalah dusun Glagah desa Giling yang terletak di kecamatan Gunungwungkal, kabupaten Pati. 
Tehnik pengumpuan data merupakan langkah yang paling strategis dalam penelitian, karena tujuan utama dari penelitian adalah mendapatkan data (Sugiyono, 2013:224). Penelitian ini memiliki dua tehnik dalam pengumpulan data yaitu observasi dan wawancara. Observasi merupakan suatu proses yang kompleks, suatu proses yang tersusun dari berbagai biologis dan psikhologis.

Dua diantara yang terpenting adalah proses-proses pengamatan dan ingatan. Metode observasi adalah metode yang biasa diartikan sebagai pengamatan yang dilakukan dengan sistematis terhadap fenomenafenomena yang diselidiki. Metode ini digunakan untuk mengetahui seberapa jauh tingkat pemahaman dan praktik konsep tilakkhana didalam masyarakat Budhis dusun Glagah desa Giling kecamatan Gunungwungkal kabupaten Pati (Sugiyono,2013:145).

Sementara itu, Wawancara adalah proses tanya jawab dalam penelitian yang berlangsung dalam mana dua orang atau lebih bertatap muka mendengarkan secara langsung informasi-informasi atau keteranganketerangan cholid narbuko dan abu acha`di (2013:83). Dalam melakukan wawancara terhadap subjek dan informan peneliti tidak menggunakan waktu khusus melainkan menggunakan waktu luang para subjek dan informan. Analisis data menurut Patton (Moleong, 2001: 103) merupakan proses mengatur urutan data, mengorganisasikannya ke dalam suatu pola, kategorisasi, dan satuan uraian dasar. Menurut Bogdan dan Biklen (Moleong, 2001: 248) analisis data adalah upaya yang dilakukan dengan jalan bekerja dengan data, mengorganisasikan data, memilah-milahnya menjadi satuan yang dapat dikelola, mensintesisnya, mencari dan menemukan pola, menemukan apa yang penting dan apa yang dipelajari, dan memutuskan apa yang dapat diceriterakan pada orang lain.

Teknik analisis data yang digunakan dalam penelitian ini adalah mengacu pada konsep Milles \& Huberman dalam Moleong (2001: 20) yaitu interaktive model yang mengklasifikasikan analisis data dalam tiga langkah yaitu reduksi, penyajian data, dan penarikan kesimpulan. Reduksi data yaitu suatu proses pemilahan, pemusatan perhatian pada penyederhanaan, pengabstrakan dan transformasi data kasar yang muncul dari catatan-catatan tertulis di lapangan. Sedangkan Penyajian data ini tersusun sedemikian rupa sehingga memberikan kemungkinan adanya penarikan kesimpulan dan pengambilan tindakan. 
Adapun bentuk yang lazim digunakan pada data kualitatif terdahulu adalah dalam bentuk teks naratif. Penarikan kesimpulan dalam penelitian ini akan diungkap mengenai data yang dikumpulkan. Dari data tersebut akan diperoleh kesimpulan yang tentatif, kabur, kaku dan meragukan, sehingga kesimpulan tersebut perlu diverifikasi. Verifikasi dilakukan dengan melihat kembali reduksi data maupun display data sehingga kesimpulan yang diambil tidak menyimpang.

Teknik pengambilan kesimpulan pada penelitian ini menggunakan Triangulasi yaitu dengan menggunakan teknik mengumpulkan tokoh masyarakat yang berada di tempat penelitian kemudian peneliti sendiri sehingga disebut triangulasi karena kesimpulan yang di ambil bukan kesimpulan sepihak melainkan kesimpulan dari beberapa pihak.

\section{Pembahasan}

Masyarakat adalah sekelompok orang yang membentuk sebuah sistem semi tertutup, dimana sebagian besar interaksi adalah antara individuindividu yang berada dalam kelompok tersebut. Masyarakat juga bisa diartikan sebagai tempat berkumpulnya manusia yang memiliki tujuan yang sama dan menempati pada wilayah yang sama, dengan menggunakan kegotongroyongan. Masyarakat Buddhis adalah masyarakat yang secara khusus beragama Buddha, bukan masyarakat pada umumnya.

Masyarakat Buddhis sebagian kecil sudah mengetahui pokok-pokok dasar dalam agama Buddha, tetapi sebagian besar masyarakat Buddhis belum mengetahui tentang pokokpokok dasar dalam agama Buddha. Pokok-pokok dasar agama Buddha adalah ajaran Buddha yang sangat mendasar, seharusnya umat Buddha sudah memahami.

Pokok yang mendasar dalam agama Buddha yaitu Triratna, Brahma Vihara, Panca kanda atau Pansa Skanda, Hukum Karma, dan masih bayak lainnya. Dari banyaknya pokok yang mendasar dalam agama Buddha, ada satu pokok mendasar yang memiliki ciri tersendiri, yaitu tilakkhana. Tilakkhana memiliki keunik tersendiri untuk dibahas, karena dalam tilakkhana mengandung tiga aspek kehidupan dalam pandangan agama Buddha yang sudah terbukti dan sudah dirasakan oleh umat Buddha dalam kehidupan sehari-hari. 


\section{Pengertian Tilakkhana}

Hukum tilakkhana termasuk Hukum Kebenaran Mutlak, artinya bahwa hukum ini berlaku dimanamana dan setiap waktu (tidak terikat oleh waktu dan tempat). Hukum tilakkhana ini mengacu pada 3 corak kehidupan yang pasti terjadi dan terdapat pada segala sesuatu yang berkondisi (Sasanasena Seng Hansen, 2008 : 11). Ciri ini merupakan salah satu bentuk dari hukum kebenaran mutlak (Paramatha-sacca) karena berlaku dimana saja dan kapan saja. Oleh karena itu, tilakkhana merupakan corak yang universal. Satu kata yang sederhana ini, anicca (ketidakkekalan), merupakan inti dari ajaran Buddha. Makhluk hidup juga ditandai dua sifat kehidupan lain, penderitaan (dukkha) dan tanpa inti (anatta).

\section{Anicca (Tidak Kekal)}

Anicca berasal dari kata "an" yang merupakan bentuk negatif atau sering diterjemahkan sebagai tidak atau bukan. Dan "nicca" yang berarti tetap, selalu ada, kekal, abadi. Jadi kata "annicca" berarti tidak tetap, tidak selalu ada, tidak kekal, tidak abadi, berubah. Dalam bahasa Sanskerta disebut juga sebagai anitya. Sabbe sankhara anicca berarti segala sesuatu yang berkondisi (terbentuk dari perpaduan unsur) akan mengalami perubahan (tidak kekal). (Majjhima Nikaya I : 228).

Anicca (Ketidak-kekalan) merupakan suatu fakta yang bersifat Universal. Hal ini berlaku bagi manusia, gagasan, pemikiran dan perasaan, bagi hewan, tanaman, gunung, sungai atau segala sesuatu yang mungkin bisa kita beri nama. Ketidak-kekalan adalah suatu fakta yang tak terhindarkan. Segala sesuatunya mengalami perubahan yang konstan dari waktu ke waktu, seperti halnya suatu proses, kehamilan berlanjut ke proses kelahiran, bayi tumbuh menjadi anak-anak, anak-anak tumbuh mejadi remaja, remaja tumbuh menjadi dewasa, lalu menjadi tua dan mati.

Semua fenomena yang ada didalam alam semesta ini selalu mengalami perubahan yang tak putusputusnya, selalu dalam keadaan bergerak dan mengalami proses. Tidak ada sesuatupun yang tetap sama selama dua saat yang berturut-turut walaupun dalam perbedaan detik. Hukum anicca bersifat netral dan tidak memihak. Karena segala sesuatu merupakan hasil dari sebab-sebab dan kondisi yang berubah, maka segala sesuatu juga terus-menerus berubah. 


\section{Dukkha (Penderitaan)}

Dukkha berasal dari kata " $d u$ " yang berarti sukar dan kata "kha" yang berarti dipikul, ditahan. Jadi kata " $d u$ kha" berarti sesuatu atau beban yang sukar untuk dipikul. Pada umumnya dukkha dalam bahasa Indonesia diartikan sebagai penderitaan, ketidakpuasan, beban. Sabbe sankhara dukkha berarti segala sesuatu yang berkondisi, terbentuk dari perpaduan unsur, merupakan sesuatu yang tidak memuaskan yang akan menimbulkan beban berat atau penderitaan.

Mengapa segala fenomena tidak memuaskan dan menimbulkan beban berat atau penderitaan? Hal ini dikarenakan segala fenomena tersebut mengalami perubahan, tidak kekal. Dan ketika kita tidak bisa memahami dan menerima bahwa segala fenomena selalu mengalami perubahan, tidak kekal, maka timbul perasaan ketidaksukaan, ketidakpuasan pada diri kita dan akhirnya menimbulkan beban berat atau penderitaan. Didalam Ajaran Empat Kebenaran Mulia, pengertian tentang dukkha tidak terbatas pada penderitaan saja. Dalam arti yang lebih luas, dukkha bisa juga berarti ketidak puasan, ketidak sempurnaan atau ketidak abadian.
Di dalam pengertian SankharaDukkha, ditekankan bahwa tidak ada suatu diri atau atta yang berada di balik Pancakkhandha ini yang akan merasakan dukkha, bahwa dukkha itu timbul akibat kondisi-kondisi yang tercakup di dalam kelima khandha yang selalu bergerak dan berubah-ubah, pula tidak ada sesuatupun yang berada di luar kondisi yang berubah-ubah tersebut yang menggerakkan atau yang menyebabkan perubahan-perubahan itu, bahwa yang ada hanyalah perubahanperubahan itu sendiri.

\section{Anata (Tiada Inti Diri)}

Anatta adalah kata bahasa Pali yang berasal dari awalan "an" yang sering diterjemahkan sebagai tidak, bukan atau tiada. "atta" berarti "inti", diri sejati, roh, atau jiwa. Dalam bahasa Sanskerta disebut juga sebagai anatman. Jadi kata "an-atta" berarti bukan diri sejati” atau dalam konteks penulisan ini, anatta akan diterjemahkan sebagai "Tiada inti diri”. Kata atta mempunyai makna yang luas dan dapat ditemukan dalam bidang ilmu psikologi, filsafat, maupun peristilahan sehari-hari, contohnya, atta dapat berarti "diri", "mahkluk", "ego", "jiwa", "roh", "aku" atau "kepribadian". 
Pemahaman Tilakkhana dalam Kehidupan Masyarakat Buddhis di Desa Giling

Pemahaman berasal dari kata paham yang artinya pengetahuan yang banyak. Pemahaman tilakkhana dalam kehidupan masyarakat Buddhis di desa Giling, adalah seberapa luas atau seberapa banyak masyarakat Buddhis di desa Giling mengetahui arti dari tilakkhana. Masyarakat Buddhis di desa Giling sudah lama menganut ajaran Buddha, yaitu kurang lebih sejak sekitar 50an tahun yang lalu.

Penulis mencoba melakukan riset, tentang sejauh mana pemahaman tilakkhan masyarakat Buddhis di desa Giling. Hasil yang didapatkan penulis sangat memprihatinkan, dari beberapa orang yang diwawancarai penulis, banyak diantara mereka yang belum mengetahui apa yang di maksud dengan tilakkhana. Delapan dari sepuluh orang yang diwawancarai penulis belum mengetahui arti dari tilakkhana secara terpenci. Dari sepuluh orang hanya dua yang bisa menjelaskan tilakhana dengan baik.

Penulis mendatangi seorang Ibu di dusun Glagah desa Giling kecamatan Gunungwungkal kabupaten Pati yang bernama Ibu Warsih kira-kira berumur 55 tahun. Penulis bertanya "nopo ingkang panjenengan mangertosi babagan konsep ajaran Buddha kukum tilakkhana?”. Warsih. (2018 Mei 15).

Kulo dereng mangertosi nopo niku tilakkhana, kulo mboten kemutan menawi sampun medal saking vihara”. Umat Buddha di desa Giling kecamatan Gunungwungkal kabupaten Pati kebanyakan sudah berumur tua, sedangkan generasi yang lahir ditahun 80an, kurang minat untuk mempelajari ajaran- ajaran Buddha. Wajar apabila umat yang berusia 50 tahun keatas tidak memahami konsep tilakkhana. Tetapi yang membuat prihatin ketika seorang ibu-ibu yang masih produktif tidak mengetahui konsep dari tilakkhana.

Apabila anak-anak di kehidupan masyarakat Desa Giling bertanya tentang ajaran-ajaran agama Buddha, mereka kebingungan dan tidak bisa menjawab, hal ini yang menjadi kemerosotan agama Buddha di Desa Giling. Manusia dapatmemahami suatu hal karna proses belajar, yaitu diawali dengan niat ingin tahu dan rasa penasaran, sehingga termotivasi untuk mencari tahu. Manusia memiliki banyak metode untuk belajar salah satunya adalah dengan cara membaca. Membaca adalah suatu metode yang kita gunakan untuk berkomunikasi dengan diri kita sendiri dan kadang- 
kadang dengan orang lain yaitu mengkomunikasikan makna yang terkandung pada lambang-lambang tertulis (Tarigan, 2008:8). Membaca adalah memahami isi ide atau gagasan baik tersurat maupun tersirat bahkan tersporot dalam bacaan. Dengan demikian, pemahaman yang menjadi produk pembaca yang bisa diukur, bukan perilaku fisik duduk berjam-jam diruang belajar sambil memegang buku (Saddhono, dan Slamet, 2014: 101).

Sementara itu, Achmad dan Alek (2011:75) menjelaskan bahwa membaca ialah proses memahami pesan tertulis yang menggunakan bahasa tertentu yang disampaikan oleh penulis kepada pembaca. Berdasarkan kutipan diatas dapat disintesiskan bahwa membaca adalah proses komunikasi lisan yang dilakukan untuk memahami sebuah gagasan baik yang tersirat maupun yang tersurat melalui sarana yang di sajikan penulis kepada pembaca. Apabila masyarakat Buddhis di Desa Giling memiliki kemauan untuk belajar membaca buku-buku, artikel, jurnal yang memuat ajaran agama Buddha, nantinya masyarakat Buddhis di Desa Giling akan memahami konsep-konsep dasar agama Buddha salah satunya tilakkhana. Media sosial sudah mudah diakses dimana-mana, masyarakat Buddhis di
Desa Giling tidak perlu bersusah payah untuk belajar untuk mencari buku-buku secara manual. Masyarakat Buddhis di Desa Giling bisa memanfaatkan internet untuk belajar mencari informasi mengenai ajran-ajaran agama Buddha, baik dari artikel, jurnal, dan lain sebagainya.

Masyarakat Buddhis di Desa Giling masih memiliki rasa malas. Rasa malas adalah rasa dimana seseorang memiliki rasa bermalas-malasan tidak tergerah hatinya untuk melakukan aktivitas tertentu. Masyarakat Buddhis di Desa Giling kurang adanya minat untuk belajar dan memahami ajaranajaran Buddha khususnya hukum tilakkhana karena masih memiliki kemelekatan terhadap rasa malas yang dimiliki. Masyarakat Buddhis di Desa Giling belum memahami konsep ajaran agama Buddha tilakkhana.

Hanya sebagian kecil saja yang telah memahami konsep agama Buddha tilakkhana, sedangkan yang lainnya masih belajar untuk bisa memahami tilakkhana dan untuk bisa menjelaskan arti dari tilakkhana kepada orang-orang terdekat, khususnya kepada anak-anak yang masih membutuhkan bimbingan dalam belajar. 
Penerapan Tilakkhana Dalam

Kehidupan Masyarakat Buddhis di

\section{Desa Giling}

Menurut Kamus Besar Bahasa

Indonesia (KBBI) 2020, pengertian penerapan adalah perbuatan menerapkan. Sedangkan menurut beberapa ahli berpendapat bahwa, penerapan adalah suatu perbuatan mempraktikkan suatu teori, metode, dan hal lain untuk mencapai tujuan tertentu dan untuk suatu kepentingan yang diinginkan oleh suatu kelompok atau golongan yang telah terencana dan tersusun sebelumnya.

Dari hal tersebut dapat diartikan penerapan tilakkhana dalam kehidupan masyarakat Buddhis di desa Giling adalah bagaimana masyarakat Buddhis di desa Giling bisa mempraktikkan teori-teori dari konsep hukum tilakkhana. Mempraktikkan konsep hukum tilakkhana untuk mencapai tujuan membebaskan penderitaan dan memperoleh kedamaian dalam kehidupan masyarakat Buddhis di desa Giling.

Dengan mempraktikkan konsep hukum tilakkhana, masyarakat Buddhis di desa Giling secara tidak langsung telah menambah keyakinan (saddha) terhadap ajaran Buddha. Keyakinan adalah kepercayaan dan sebagainya yang sungguh-sungguh, kepastian, ketentuan, bagi agama atau religi berwujud konsep yang menjadi keyakinan para penganutnya. Keyakinan dalam agama Buddha adalah keyakinan terhadap Tiratana atau keyakinan terhadap Buddha, keyakinan terhadap Dhamma, dan keyakinan terhadap Sanggha. Saddha berarti keyakinan berdasarkan kebijaksanaan, keyakinan disini berarti meyakini sesuatu yang memang patut diyakini.

Sebagian besar masyarakat Buddhis di desa Giling, belum memahami konsep dari tilakkhana atau belum mengerti apa yang dimaksud dengan hukum tilakhhana. Walaupun masyarakat Buddhis di desa Giling kecamatan Gunungwungkal kabupaten Pati belum mengerti dengan konsep hukum tilakkhana atau dengan sebutan anicca (ketidak kekalan), dukkha (penderitaan), dan anata (tanpa inti/tanpa keakuan), tetapi $60 \%$ masyarakat Buddhis di Desa Giling sudah belajar untuk mempraktikan atau menerapkan kosep hukum tilakkhana di dalam kehidupan sehari-hari.

Masyarakat Buddhis di desa Giling secara tidak sadar sudah belajar menerapkan kosep ajaran Buddha tilakkhan, karena masyarakat Buddhis di desa Giling belum memahami pengertian konsep ajaran agama 
Buddha tilakkhana. Masyarakat Buddhis di desa Giling kebanyakan sudah belajar memahami bahwa semua yang ada didunia semua dapat berubah, semua yang dimiliki dapat berubah. Masyarakat Buddhis di desa Giling sudah melajar untuk memahami bahwa penderitaan akan selalu mengikuti apabila masih belum menerima kenyataan tentang semua yang ada akan berubah tidak kekal adanya. Masyarakat Buddhis di desa Giling sudah belajar memahami apabila keakuan atau semua diatasnamakan milikku, suatu saat apabila yang dimiliki akan berubah bisa menimbulkan penderitaan.

Penulis mengamati kasus yang dialami keluarga Bapak Sukasan dan Ibu Warsih, Bapak Sukasan dan Ibu Warsih memiliki kambing yang 5 ekor. Didalam banyaknya kambing, ada satu kambing dengan kelamin jantang yang ditawar pembeli dengan harga 2,5 juta, tetapi tidak di berikan. Suatu ketika kambing yang tersebut mati karna keracunan daun singkong. Apabila mereka tidak mengetahui konsep yang akan mengalami ketidak kekalan, dan apabila tidak bisa melepas akan menimbulkan penderitaan, Bapak Sukasan dan Ibu Warsih akan terus larut dalam kesedihan yang menimbulkan penderitaan, apabila tidak menerapkan konsep tilakkhana dalam aspek kehidupan. Bapak Sukasan dan Ibu Warsih tanpa ada rasa menyesal, Bapak Sukasan dan Ibu Warsih belajar untuk memahami dan menerima hal tersebut, karena Bapak Sukasan dan Ibu Warsih mengetahui bahwa semua yang ada didunia ini bukan miliknya dan juga semua yang ada di dunia ini wajar berubah wajar terpisah. Bapak Sukasan dan Ibu Warsih memahami apabila tidak bisa melepaskan, tidak bisa menerima, pasti penderitaan yang akan di dapatkan bukan kedamaian.

Dengan adanya kasus diatas membuktikan bahwa masyarakat sudah mempraktikan konsep tilakkhana didalam kehidupan sehari-hari. Pada dasarnya masyarakat Buddhis di desa Giling sudah mulai belajar sedikit demi sedikit untuk menerapkan konsep hukum tilakkhana dalam kehidupan sehari- hari. Masyarakat Buddhis di desa Giling sudah berusaha untuk belajar mempraktikkan konsep dasar agama Buddha hukum tilakkhana.

\section{Simpulan}

Konsep tilakkhana dalam kehidupan masyarakat Buddhis di desa Giling dapat di simpulkan bahwa, tilakkhana atau adalah tiga corak umum atau kadang disebut tiga corak kehidupan 
yaitu, aniccha, dukkha, dan anatta, merupakan tiga corak umum yang ada disetiap segala sesuatu atau fenomena yang terbentuk dari perpaduan unsur (berkondisi) yang ada dialam semesta ini, termasuk makhluk hidup. Masyarakat Buddhis di desa Giling sebagian besar belum memahami kosep dari hukum tilakkhana, karena kurangnya minat belajar.

Selain itu karna usia mereka yang sudah cukup tua, sehingga mengurangi minat mereka untuk mempelajari ajaran-ajaran agama Buddha. Walaupun masyarakat Buddhis di Desa Giling belum memahami tentang arti dari hukum tilakkhana tetapi masyarakat Buddhis di Desa Giling sebagian besar sudah menerapkan konsep hukup tilakkhana dalam kehidupan sehari-hari.

\section{Daftar Pustaka}

Hansen, Sasanasena Seng. 2008.

Ikhisar Ajaran Agama Buddha.

Yogyakarta:Vidyasena Production.

Moleong, Lexy J. 2001. Metode Penelitian Kualitatif. Bandung: PT. Remaja.

Narbuko, Cholid \& Achmaadi, Abu. 2013. Metodologi Penelitian Memberi Bekal

Teoritis Pada Mahasiswa

Tentang Metodologi Penelitian

Serta Diharapkan Dapat

Melaksanakan Penelitian Dengan Langkah-langkah Yang Benar. Jakarta. Bumi.
Sugiyono. 2013. Metode Penelitian Kuantitatif, Kualitatif dan $R \& D$. Bandung: Alfabeta.

Tanhadi. 2010. Tiga Corak Umum (Tilakkhana). Jakarta:Pustaka Dhamma

Tarigan, Henry. 2008. Membaca Sebagai Suatu Keterampilan Berbahasa. Bandung:Angkasa. 